\title{
TUBULARIA CAMPANULATA.
}

Q

CHARACTER GENERICUS.

Stirps tubulofa, fimplex vel ramofa, bafi affixa. Animal terminale, capite tentaculis criftato.

CHARACTER SPECIFICUS, E?C.

TUBULARIA cryftallina tentaculis lunatis, receptaculo fimplici vel multifido-palmato.

TUBULARIA cryftallina.

$$
\text { Pall. elench. zooph. p. } 85 \text {. }
$$

TUBULARIA campanulata.

$$
\text { Lin. Syft. Nat. p. } 1303 .
$$

TUBULARIA reptans.

$$
\text { Lin. Syft. Nat. Gmel. p. } 3835 \text {. }
$$

POLYPI criftati.

Trembl. polyp. 3.p. 209. t. 10. f. 8. 9.

Animalium minorum aquaticorum in pulcherrimis eft quod in tabula depingitur tum aucta, tum naturali magnitudine. Aquas incolit puriores ftagnantes, decem nempe, duodecim, feu quindecim in communi 
muni receptaculo gregatim degentibus, fingulo tamen motus fuos ad libitum, et fine impedimento exercente. Totam congeriem, qualis nudo oculo cernitur fine ope inftrumentorum opticorum, repræfentat minor tabulæ figura. Affigitur, ut plurimum, hæc congeries fibris radicularum in aquis immerfarum, aut caulibus plantarum aquaticarum, Lemnæ $f$ cilicet, Veronic $æ$ Beccabungæ, aliarumque plurium. Singulo animalculo corpus eft fub-cylindraceum, tubulatum, hyalinum, in tubo majore inclufum; e quo pars fuperior ad libitum protruditur ; qui tubi majores connectuntur cum ipfo receptaculo communi, gelato, nec longe abfimili quafi campanulatæ veficæ marginem habenti in fegmenta aliquot truncato-tubulata incifum. Caput unicuique feu pars fuperior conftat e membris duobus amplis, femicirculatis, tenfilibus, quorum numerofiffima tentacula difponuntur quafi in formam literæ $\int$; expanfaque fimilia quodammodo funt calceamento equino. Tota conglomeratio vitreo-hyalina eft; fibrarumque quaquaverfum velociffime commotarum elegantem et veram proportionem nequit fideliter fatis attingere ars fculptoria ; non nifi ipfius animalculi intuitu plene percipiendam; cum fingulis tentaculis fua et peculiaris infit pulchritudo. Tentaculorum ope gyratis quafi in vorticem aquis, varia fortaffe animalcula in os facilius attrahuntur. $\mathrm{Si}$ fubito turbantur Tubularix, dicto citius intra tubos majores et exteriores fefe recipiunt; et horæ momento iterum extenduntur; funt enim impatientes carceris, gaudentque, ut plurimum, membris liberis 
et expanfis ; quo tempore de forma et motu generali vel nudo oculo poffit judicari. Sunt præterea ea magnitudine ut non opus fit pollentibus inftrumentis, fed lente tantum cujus (ut optici loquuntur) uncialis fit focalis diftantia. Ut tamen fingulæ partes plene et penitius examinentur, neceffe omnino eft microfcopio uti.

Menfibus æftivis confpici poffint pulcherrima hæc animalcula in variis aquis Londino adjacentibus. Inveniebantur Tubulariæ quas repræfentat tabula, Augufto menfe, juxta ambulacrum Chelfeanum, a falicibus Willow-Walk dictum; qua etiam in aqua nec non in aliis pluribus fuburbanis habitat Hydra communis feu viridis. 


\section{CAMPANULATED TUBULARIA.}

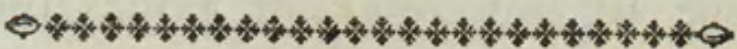

\section{GENERIC CHARACTER.}

Stem tubular, fimple or branched, fixed by the bafe.

Animal terminal; the head crefted with tentacula.

$$
\text { SPECIFIC CHARACTER, ËC. }
$$

Cryftalline TUBULARIA with tentacula difpofed in the form of a crefcent; the receptacle either fimple, or more or lefs palmated.

Veficular frefh-water TUBULARIA.

FEATHER-POLYPE, or Bell-Polype.

POLYPES à panache.

\section{Trembl.}

The BELL-FLOWER ANIMAL, or Plumed Polype.

$$
\begin{array}{r}
\text { Baker. Empl. for. Micr. p. } 306 . \\
\text { pl. 12. f. 15-20. }
\end{array}
$$

Among the moft beautiful of the fmaller aquatic animals may moft juftly be ranked that reprefented on the prefent plate both in its natural fize as well 


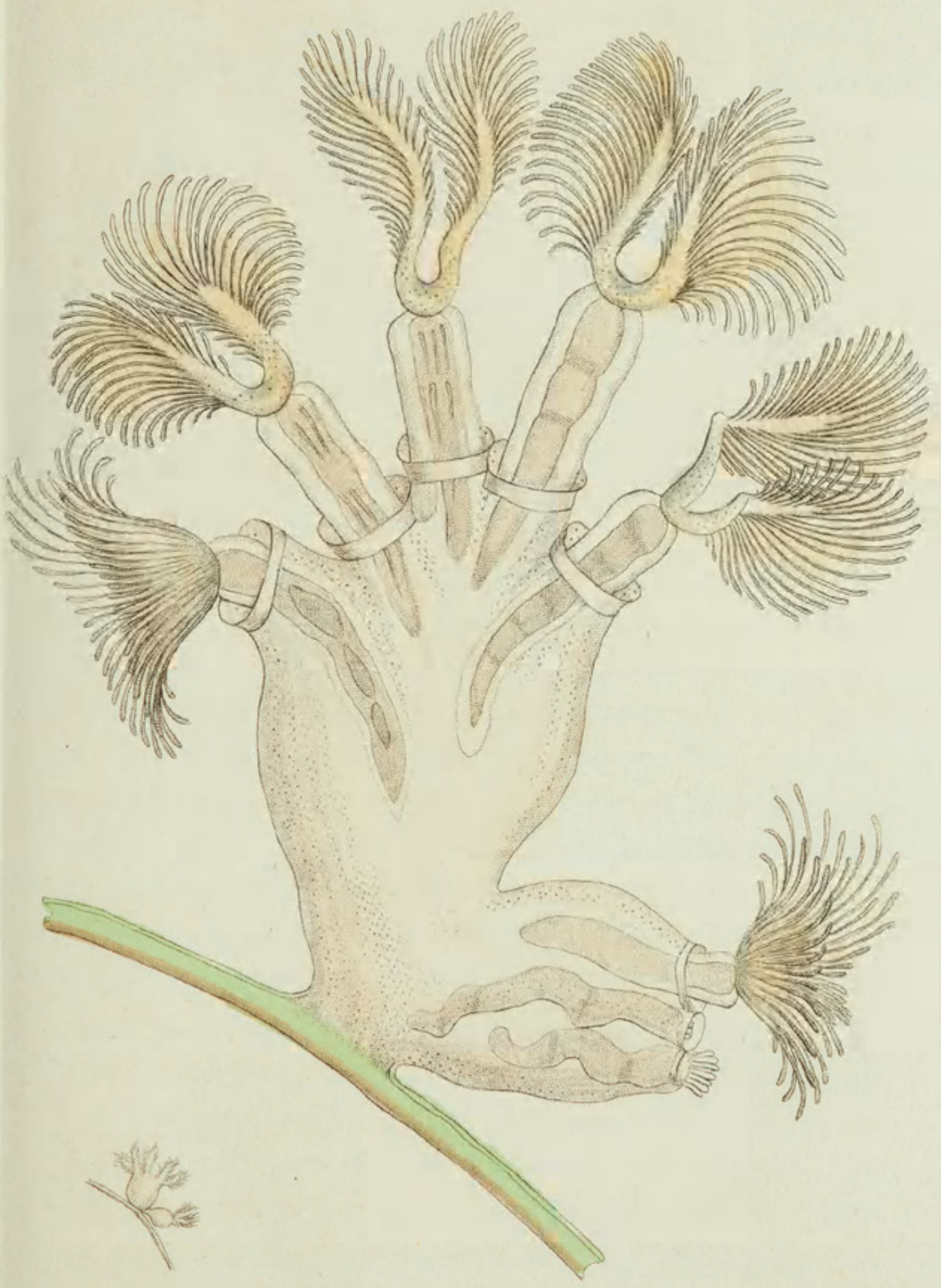

Oct', $9^{8} \times \mathcal{P}$. Nodder, 

as magnified. It is a native of clear ftagnant waters, living in a kind of congregated manner; feveral individuals to the number of ten, twelve, or fifteen, inhabiting a common or general receptacle: each exerting its own voluntary motions independent of the reft. To the naked eye the whole groupe appears of the fize reprefented by the fmaller figure. It is generally attached either to the fmall fibres of roots projecting into the water, or to the ftems of aquatic plants as Lemna, Brooklime, and others. The body of each animal is tranfparent, of a fubcylindric, tubular form, and is included in a larger or exterior tube, from which the head or upper part is at pleafure protruded. The larger or exterior tubes are connected to the veficular and fomewhat bell-fhaped general receptacle, which is of a gelatinous fubftance, and is divided at the top or border into feveral tubular, truncated fegments. The head of the animal confifts of two large, femicircular, expanfile parts or organs, the tentacula of which are extremely numerous, in thape refembling an italic $f$, and, when expanded, reprefenting in fome meafure the figure of an horfe-fhoe. The whole is of a glaffy tranfparency, and the various flexures of the tentacula, moving with rapidity in different directions, afford a fpectacle which it is not poffible by any engraving to exprefs with fufficient exactnefs, fince nothing but an actual view of the animal can convey a genuine idea of this particular; every varying pofition of the tentacula difplaying an elegance peculiar to itfelf. When difturbed they fuddenly 
denly withdraw into the larger or exterior tubes, and in a moment or two afterwards again extend themfelves: they even feem impatient of confinement, and are commonly feen with the heads expanded, in which ftate their general fhape and motions may be obferved with the naked eye; and indeed the fize of this animal is fuch as not to require the affiftance of powerful magnifiers, but may be viewed to confiderable advantage by a lens of an inch focus; though in order to examine with accuracy its feveral parts it is neceffary to make ufe of a microfcope.

Thefe beautiful Zoophytes may be found during the Summer months in various waters in the neighbourhood of the Metropolis : the fpecimens reprefented on the prefent plate were difcovered in the water by the fide of the Willow-Walk at Chelfea, in which, as well as in feveral of the neighbouring waters, may alfo be found the Hydra viridis or common green Polype. 


\section{$2 \mathrm{BHL}$ Biodiversity Heritage Library}

Shaw, George. 1798. "Campanulated Tubularia, Tubularia campanulata [PI. 354]." The Naturalist's Miscellany 10(CX), https://doi.org/10.5962/p.304536.

View This Item Online: https://www.biodiversitylibrary.org/item/276641

DOI: https://doi.org/10.5962/p.304536

Permalink: https://www.biodiversitylibrary.org/partpdf/304536

\section{Holding Institution}

Museums Victoria

\section{Sponsored by}

Atlas of Living Australia

\section{Copyright \& Reuse}

Copyright Status: Public domain. The BHL considers that this work is no longer under copyright protection.

This document was created from content at the Biodiversity Heritage Library, the world's largest open access digital library for biodiversity literature and archives. Visit BHL at https://www.biodiversitylibrary.org. 